\title{
TEPUNG MAKANAN SEBAGAI ALTERNATIF PERINTANG DALAM PENCIPTAAN KARYA SENI TEKSTIL
}

\author{
Djandjang Purwo Sedjati ${ }^{1}$ \\ (Jurusan Kriya, Fakultas Seni Rupa, ISI Yogyakarta, mrs.djandjang@gmail.com, 08122791265) \\ Agung Suhartanto ${ }^{2}$ \\ (Jurusan Kriya, Fakultas Seni Rupa, ISI Yogyakarta, manusiabatiki@gmail.com, 081578525799)
}

\begin{abstract}
The establishment of batik as a humanitarian legacy for oral and non-material culture (Masterpieces of the Oral and Intangible Heritage of Humanity) by UNESCO on October 2, 2009 and the establishment of Yogyakarta as the World Batik City by the World Craft Council made batik gained enthusiastic in the community. On the other hand, batik has to deal with people's demands for new products that can fulfill their desires. Thus, new creations that are creative and innovative are needed in order to fulfill theconsumers and the market needed. From the description above, there was an interest in creating creative works of art by exploring non-evening materials in the form of food flour, namely sago flour and cornstarch as other alternatives in the creation of batik and textile art. As for rice, starch and sticky rice are not used because in Japan, rice has been used as a barrier called Katazome, in Negeria, starch has been used as a barrier called Adire Eleko and in the past sticky rice was used in the manufacture of simbut fabrics in Sunda West Java. To collect data, the researcher used the library method and observation method. As for the implementation methods used the Practiced Led Research method which is a type of practical research, which is creating and reflecting new work through practical research conducted (Hendriyana, 2018: 21). The Three Step Six Step Gustami Art Pattern Creation Method is used to explore the source of ideas and design. Experiments and Improvisation Methods are also carried out by the researcher to get new knowledge from experiments conducted mainly on non-batik material in the form of food flour. In this creation, wheat flour, cornstarch, and sago flour will be used as non-wax material then the non-wax material will be applied and the application of the non-wax material will be combined with batik wax. In this creation fast dye will be applied. There are 5 types of textile art works that will be made, namely long cloth, shawl, chair cushions, and scrafs as functional works and wall hanging or wall hangings as expressive artwork.
\end{abstract}

KeywordS: flour porridge, batik, color synstetically

\section{ABSTRAK}

Ditetapkannya batik sebagai warisan kemanusiaan untuk budaya lisan dan non bendawi (Masterpieces of the Oral and Intangible Heritage of Humanity) oleh UNESCO pada tanggal 2 Oktober 2009 dan ditetapkannya Yogyakarta sebagai Kota Batik Dunia oleh World Craft Council menjadikan seni batik kembali bergairah di tengah masyarakat. Disisi lain, batik harus berhadapan dengan permintaan atau tuntutan masyarakat akan produk-produk baru yang dapat memenuhi keinginan mereka. Dengan demikian, diperlukan ciptaan-ciptaan baru yang kreatif dan inovatif dalam rangka untuk memenuhi kebutuhan konsumen dan pasar. Berangkat dari uraian tersebut diatas, muncul ketertarikan untuk menciptakan karya seni kreatif dengan mengeksplorasi bahan non malam berupa tepung makanan yaitu sagu terigu dan maizena sebagai alternatif lain dalam penciptaan seni batik dan tekstil. Adapun beras, kanji dan ketan tidak digunakan karena di Jepang, beras sudah digunakan 
sebagai perintang yang disebut Katazome, di Negeria, tepung kanji sudah digunakan sebagai perintang yang disebut Adire Eleko dan pada masa lampau ketan dipakai dalam pembuatan kain simbut di Sunda Jawa Barat. Untuk mengumpulkan data digunakan metode pustaka dan metode observasi. Adapun pada pelaksanaannya digunakan metode antara lain metode Practiced Led Research yang merupakan jenis penelitian praktik, yaitu menciptakan dan merefleksikan karya baru melalui riset praktek yang dilakukan (Hendriyana,2018:21). Metode Penciptaan Seni Kriya Pola Tiga Tahap Enam Langkah Gustami digunakan untuk menggali sumber ide dan perancangan. Metode Eksperimen dan Improvisasi juga dilakukan penulis untuk mendapatkan pengetahuan baru dari eksperimen yang dilakukan terutama pada bahan non malam batik berupa tepung makanan. Pada penciptaan ini, akan digunakan tepung terigu, tepung maizena, dan tepung sagu sebagai material non malam kemudian diaplikasikan bahan perintang non malam batik dan aplikasi paduan bahan perintang non malam batik dengan malam batik. Pada penciptaan ini akan diterapkan pewarnaan fast dye. Ada 5 jenis karya seni tekstil yang akan dibuat yaitu kain panjang, selendang, sarung bantal kursi, dan scraf sebagai karya fungsional serta wall hanging atau hiasan dinding sebagai karya seni ekspresi.

Kata kunci: bubur tepung, batik, warna sinstetis

\section{PENDAHULUAN}

Telah kita ketahui bersama bahwa batik merupakan warisan nenek moyang yang tak ternilai harganya. Dalam sejarah keberadaannya yang mengalami pasang surut, batik menjadi sandaran bagi sebagian masyarakat Indonesia untuk mencari nafkah, menjadi salah satu kegiatan ekonomi yang menghidupi banyak orang. Dengan ditetapkannya batik sebagai warisan kemanusiaan untuk budaya lisan dan non bendawi (Masterpieces of the Oral and Intangible Heritage of Humanity) oleh UNESCO pada tanggal 2 oktober 2009 tentu saja kita sambut baik, sebab pengakuan ini sekaligus sebagai bentuk pengakuan budaya Indonesia sebagai bagian dari budaya dunia. Pengakuan ini menjadikan seni batik kembali bergairah ditengah masyarakat sekaligus melegakan bangsa Indonesia bahwa batik terhindar dari kepemilikan atas bangsa atau negara lain. Usaha seni kerajinan batik tumbuh dan berkembang lagi di berbagai daerah di Indonesia. Perlu diketahui pengukuhan ini juga membawa konsekuensi bahwa batik harus tetap berkembang dalam kehidupan masyarakat Indonesia, sebab bila kehidupan batik tidak tumbuh dalam kehidupan masyarakat Indonesia, maka predikat tersebut akan dicabut kembali oleh UNESCO.

Pada awalnya batik berfungsi sebagai pemenuh kebutuhan masyarakat yang mecakup sandang atau busana tradisional dan keperluan upacara adat daur hidup dan telah berkembang sebagai busana sehari- hari (busana modern), barang- barang fashion atau elemen interior, bahkan batik menjadi pendukung utama sektor pariwisata yang sangat potensial baik sebagai cenderamata ataupun menjadi acara kunjungan wisata batik dimana wisatawan yang berkunjung ketempat kegiatan produksi batik tidak hanya dapat membeli dan melihat proses pembuatannya tetapi dapat ikut praktek membuat batik. Tidak dapat dipungkiri bahwa batik Indonesia sangat digemari dan dikagumi tidak saja oleh bangsa kita sendiri tetapi bangsa asing pun menggemari dan mengagumi batik karena keunikannya, sehingga batik Indonesia dapat dikatakan sudah menginternasional..

Di era pasar bebas ini tentu ada hal-hal yang menimbulkan kekhawatiran, bagaimana menghadapi persoalan-persoalan yang muncul, misalnya produk- produk semacam batik dari 
luar negri yang masuk ke Nusantara sehingga menjadi persaingan. Perlu diketahui bahwa meskipun Indonesia memperoleh pengakuan UNESCO sebagai asal batik dan menjadi produsen batik terbaik dan terbesar di dunia, namun Indonesia bukan satu satunya negara penghasil batik, seperti Cina, Malaysia, India, Jepang, Thailand, Afrika Selatan dan masih ada beberapa negara lainnya.

Disisi lain, batik harus berhadapan dengan tuntutan dan dinamika selera masyarakat masa kini, batik harus berhadapan dengan permintaan atau tuntutan masyarakat akan produk-produk baru yang dapat memenuhi keinginan mereka. Tidak hanya kebutuhan untuk fashion dan perangkat interior yang selalu berkembang tetapi juga kebutuhan karya - karya yang dapat memberi kepuasan batin. Dengan demikian diperlukan ciptaan ciptaan baru yang kreatif dan inovatif dalam rangka untuk memenuhi kebutuhan konsumen dan pasar. Sebagai seniman dan perancang, penelitian ini sekaligus menjadi olah kemampuan dalam menciptakan sebuah karya seni tekstil yang kreatif, inovatif dan memiliki kebaruan, sebagaimana yang di ungkapkan oleh Soedarso (1990:79) bahwa:

Seni modern justru mengejar novelty, mengejar yang baru, yang lain daripada yang lain. Horizon seni modern tidak kenal batas, kecuali batas kemampuan imajinasi senimannya. Standarnyapun selalu goyah, berubah terus, sehingga apa yang sudah kita kenal pada suatu saat bisa saja tidak mungkin diciptakan untuk menyiasati seni yang baru.

Kreatifitas adalah dimilikinya kemampuan atau daya untuk mencipta yang bersifat orisinal dan imajinatif. Diungkapkan oleh Anas
(2011:11) Secara lebih terurai kreatifitas merupakan sebuah kemampuan untuk menggunakan imajinasi, wawasan dan kekuatan berfikir serta perasaan dan emosi untuk melahirkan sebuah gagasan baru.

Telah diketahui bahwa dalam pembuatan batik ada bahan khusus atau khas yang digunakan sebagai media perintang warna yaitu malam (lilin). Malam ini dalam proses pembuatan batik berfungsi sebagai perintang masuknya warna pada kain ketika proses pewarnaan. Bahan ini sudah teruji kekuatannya sebagai perintang warna batik yang tapak bekasnya halus dan bisa terlihat hingga detail titik titik kecil, namun sebelum ditemukannya perintang malam batik, pada masa itu digunakan bubur ketan. Diungkapkan oleh Susanto bahwa rupa rupanya dulu pada permulaan batik dibuat, sebagai bahan penutup kain dipakai bubur dari ketan dan kain yang dibuat ini disebut "kain simbut" setelah ditemukan malam maka bubur ketan ini tidak digunakan lagi ( Susanto,1980:58) Sebetulnya prinsip pembuatan kain simbut sama dengan proses membatik, hanya lebih sederhana dan dengan alat alat yang sederhana pula. Untuk alat melukis dipakai semacam kuas terbuat dari sepotong bambu yang ujungnya dipukul pukul agar dapat mengambil bubur ketan ketika bambu tadi dicelupkan pada bubur ketan ( Djumena, 1990:86) Selain di Indonesia, ada negara lain yang juga memiliki budaya semacam simbut yaitu Nigeria disebut adire eleko dengan perintang tapioka dan Jepang disebut katazome dengan perintang tepung beras

Berangkat dari alasan tersebut diatas, muncul ketertarikan dan menumbuhkan inspirasi untuk menciptakan karya seni kreatif dengan mengeksplorasi bahan bahan perintang non malam batik sebagai alternatif dalam pembuatan karya seni tekstil. Deversifikasi 
bahan perintang non malam batik merupakan hal yang penting dalam rangka pengembangan keteknikan untuk menghasilkan sebuah karya seni baru yang kreatif dan inovatif yang diharapkan dapat ditransfer ke mahasiswa dan masyarakat umum. Selain itu diharapkan pula proses keteknikan ini dapat dipakai dalam rangka pengenalan dan pembelajaran batik bagi anak anak sekolah TK dengan mengganti perintangnya. Hal ini mengingat bahwa pada tingkat usia tersebut tidak aman dan beresiko bila membatik menggunakan malam panas, tetapi aman bila menggunakan bahan perintang alternatif non malam.

Pada penelitian terapan ini, akan dilakukan eksplorasi bahan perintang non malam batik meliputi tepung bahan makanan. Beberapa jenis tepung bahan makanan akan digunakan sebagai bahan eksperimen perintangan yaitu terigu, sagu, maezina, beras, ketan dan kanji atau tapioca, namun dalam pembuatan karya dibatasi hanya tepung maizena, terigu dan sagu. Hal ini dikarenakan tepung tapioka sudah digunakan sebagai perintang pada budaya adire eleko di Nigeria, tepung beras pada budaya katazome di Jepang dan ketan pada budaya pembuatan kain simbut. Eksperimen perintangan akan dilakukan dengan cara mentah atapun dimasak disesuaikan dengan karakter bahan Bila dilihat dari bentuk dan karakter bahan yang berbeda dengan malam batik, maka proses perwujudan karyanya akan mengalami perbedaan termasuk peralatan dan pewarnaannya. Tepung-tepung ini dalam keadaan mentah atau dimasak tidak secair malam batik sehingga tidak bisa menggunakan alat canting biasa, tetapi cenderung menggunakan kuas. Mengingat perintangan secara mentah atapun dimasak melekatnya pada kain tidak tembus selekat malam, maka pewarnaannya harus secara cepat supaya perintang tidak lepas dari kain.

Ada dua jenis karya seni yang akan dibuat meliputi karya fungsional yaitu kain panjang, selendang, scarf, dan sarung bantal kursi, sedang sebagai karya non fungsional atau seni ekspresi adalah hiasan dinding. Karya seni tekstil tersebut akan diaplikasikan pada kain sutra dan katun dengan gaya kreatif mengarah kontemporer yang artistic dan lebih bebas sesuai kemampuan dan cita rasa seniman/pencipta. Untuk mendapatkan visualisasi hasil perintangan, maka dalam perwujudan karya akan diaplikasikan paduan tepung makanan dengan malam batik.

Dari uraian latar belakang di atas, maka permasalahannya dapat dirumuskan sebagai berikut :

a. Bagaimana proses pengolahan tepung makanan untuk bisa diterapkan sebagai perintang pada kain sutra dan katun?

b. Bagaimana hasil yang diperoleh dari penerapan paduan bahan perintang tepung makanan dengan malam batik pada penciptaan karya seni tekstil?

\section{METODE PENCIPTAAN}

\section{Metode Practice-led Research}

Dalam penciptaan karya ini akan digunakan metode Practice-led Research, yang merupakan jenis penelitian praktik, yaitu menciptakan dan merefleksikan karya baru melalui riset praktik yang dilakukan. Practice-led Research memiliki ciri antara lain :

a. Berfokus pada praktik proses penciptaan yang ditulis secara ilmiah, dengan mendeskripsikan proses praktek berkarya secara detail dari pra konsep hingga karya seni terwujud. 
b. Lebih mengacu pada isu dan permasalahan yang ditemukan di masyarakat/di lapangan,

c. Obyek atau benda, wujud atau bentuk karya seni belum ada ketika kegiatan penelitian dilakukan,

d. Berfokus pada menciptakan dan merefleksikan karya baru melalui riset praktik berkarya seni yang dilakukan (Hendriyana,2018:21)

Metode Practice-led Research di atas akan dikombinasikan juga dengan metode penciptaan seni Gustami sebagai pelengkap dalam penyusunan tahapan-tahapan yang dilakukan pada pelaksanaan Practice-led Research.

2. Metode Penciptaan Seni Kriya Pola Tiga Tahap Enam Langkah Gustami

Proses penciptaan karya seni dapat dilakukan melalui metode ilmiah yang direncanakan secara seksama, analitis, dan sistematis. Dalam kontek metodologis terdapat tiga tahap penciptaan karya seni yaitu Eksplorasi, Perancangan, dan Perwujudan. Dijelaskan oleh Gustami, tahapan metodenya sebegai berikut :

"Pertama, tahap eksplorasi meliputi aktivitas penjelajahan mengenai sumber ide dengan langkah identifikasi dan perumusan masalah, penelusuran, penggalian pengumpulan data dan referensi, berikut pengolahan dan analisis data untuk mendapatkan simpul penting konsep pemecahan masalah secara teoritis, yang hasilnya dipakai sebagai dasar perancangan. Kedua, tahap perancangan yang dibangun berdasarkan perolehan butir penting hasil analisis yang dirumuskan, diteruskan visualisasi gagasan dalam bentuk sketsa alternative, kemudian ditetapkan pilihan sketsa terbaik sebagai acuan reka bentuk atau dengan teknik menggambar yang berguna bagi perwujudan, bermula dari pembuatan model sesuai sketsa alternatif atau gambar teknik yang berguna bagi perwujudannya....Lebih lanjut langkah ketiga yakni tahap perancangan untuk menuangkan ide atau gagasan dari deskripsi verbal hasil analisis yang dilakukan kedalam bentuk visual dalam batas rancangan dua dimensional. Penuangan ide kreatif menjadi rnacangan dua dimensional itu dilakukan dengan pertimbangan berbagai aspek menyangkut kompleksitan nilai seni kriya, antara lain, aspek material, teknik, proses, metode, konstruksi, egonomi, keamanan, kenyamanan, keselarasan, keseimbangan, bentuk, unsure estetik, gaya, filosofi, pesan, makna, berikut fungsi social ekonomi dan budaya serta peluang masa depannya. (Gustami, Butir-Butir... 2007, 329-333).

3. Metode Eksperimen dan improvisasi Eksperimen mengolah tepung makanan untuk diterapkan pada kain sutra dan katun. Pewarnaan kain pada penciptaan karya tekstil ini digunakan pewarna kimia yang proses munculnya warna cukup cepat, mengingat bahwa tepung makanan ini tidak cukup kuat melekat pada kain, sehingga bila menggunakan pewarna dengan system rendam diduga perintang akan rusak dan lepas. Pada penciptaan ini juga akan dilakukan improvisasi bila pada tahap pelaksanaan menemukan ide ide baru sebagai variasi sepanjang sebagai penunjang karya menjadi lebih baik.

4. Metode Pengumpulan data

Untuk mendapatkan data dan refrensi dengan mencari sumber sebagai berikut :

a. Metode Pustaka

Penciptaan karya ini menggunakan metode pustaka, yaitu mencari data melalui buku, majalah, katalog, website maupun literature termasuk penelitian yang sifatnya kualitatif. Data yang diambil adalah data kualitatif yang berkaitan dengan proses penciptaan bergaya 
kontemporer dan tentang obyek penciptaan yaitu bahan bahan perintang tepung makanan

b. Metode Observasi

Dipakai untuk mendapatkan data tentang obyek yang dijadikan sumber penciptaan, yaitu tentang tepung makanan, batik simboet dan batik gaya kontemporer dengan sentuhan tradisi.

Pada pelaksanaan dilakukan dengan beberapa tahap.

A. Tahap Pengumpulan Data

1. Metode Pustaka

Pada metode pustaka, dilakukan untuk mendapatkan data mengenai material/ tepung makanan yang dapat digunakan. Beberapa buku yang digunakan sebagai acuan adalah sebagai berikut :

a. Fitriani, Hanifah., "Pengolahan Kulit Umbi Singkong (Manihot Utilissima) di Kawasan Kampung Adat Cireundeu Sebagai Bahan Baku Alternatif Perintang Warna Pada Kain", e-Proceeding of Art \& Design: Vol 4, no. 3 Desember 2017

b. Sariyati, Inva dan Utami, Prastiyo.," Pemanfaatan Pati Ganyong (Canna Edulis) Sebagai Bahan Baku Perintang Warna Pada Kain", Majalah Dinamika Kerajinan Dan Batik, Vol 35, no. 2, Desember 2018

c. Sumino, Perancangan Kain Simbut untuk Kriya Tekstil, Penelitian DIPA Tahun 2007, Lembaga Penelitian ISI Yogyakarta, September 2007

d. Suratmi.," Batik Sebagai Media Ekspresi", Tugas Akhir Prodi Kriya Seni, Jurusan Kriya, FSR, ISI Yogyakarta, 2000

\section{Metode Observasi}

Metode observasi dilakukan untuk mendapatkan informasi material tentang tepung makanan yang dapat dijadikan perintang warna tekstil. Dalam metode ini, dilakukan kunjungan wawancara ke beberapa tempat untuk pengamatan serta pencarian informasi. Kunjungan yang dilakukan adalah menuju ke beberapa tempat berikut:

a. Kunjungan ke Balai Besar Kerajinan dan Batik Yogyakarta dalam rangka mencari informasi data tentang penggunaan tepung bahan makanan yang sudah digunakan. Dari observasi ini ditembukan bahwa BBKB pernah mencoba batik simboet (menggunakan tepung ketan) namun belum pernah mencoba tepung yang lain. (Kunjungan pada tanggal 26 Juli 2019)

b. Kunjungan wawancara dengan Suratmi (Alumni ISI lulus tahun 2000) yang membuat batik Simboet pada Tugas Akhirnya namun, hingga saat ini juga belum pernah menggunakan jenis tepung yang lain. (Kunjungan pada tanggal 30 Juli 2019)

c. Kunjungan ke Galeri Sembung Batik, dalam rangka pengamatan batik gaya kontemporer. Sistem yang digunakan oleh Galeri Sembung Batik adalah teknik cabut warna dan menggunakan malam batik. Gaya kontemporer yang digunakan adalah gaya abstrak dengan motif tradisional sebagai isen. (Kunjungan pada tanggal 1 Agustus 2019)

3. Metode Practice-led Research dan Eksperimen

Pada tahap ini dilakukan pembuatan adonan dengan menggunakan air dalam peracikannya. Bahan ini dibagi menjadi dua bagian yakni bahan yang dimasak dan bahan yang mentah sehingga akan menghasilkan efek yang berbeda dari setiap tepung yang digunakan. Hasil yang didapatkan dari eksperimen ini adalah bahan masak dan 
bahan mentah. Berikut adalah hasi eksperimen yang telah dilakukan.

Tepung Terigu Mentah Basah

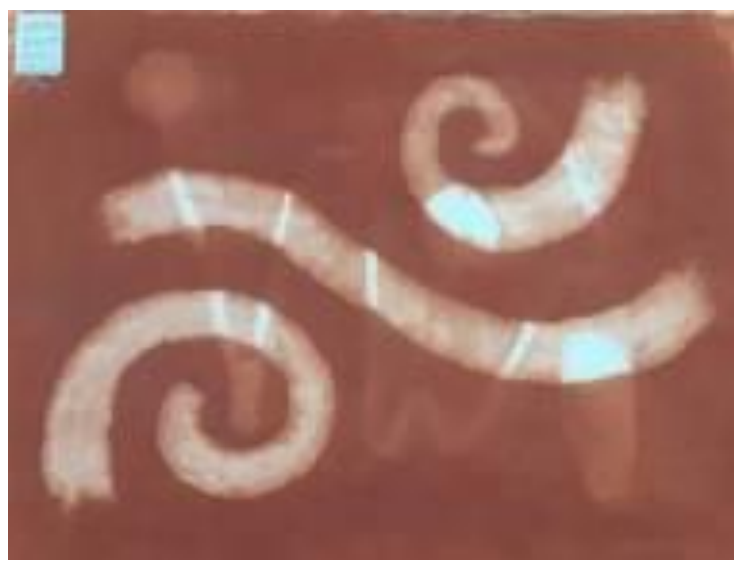

Tepung Terigu Mentah Kering
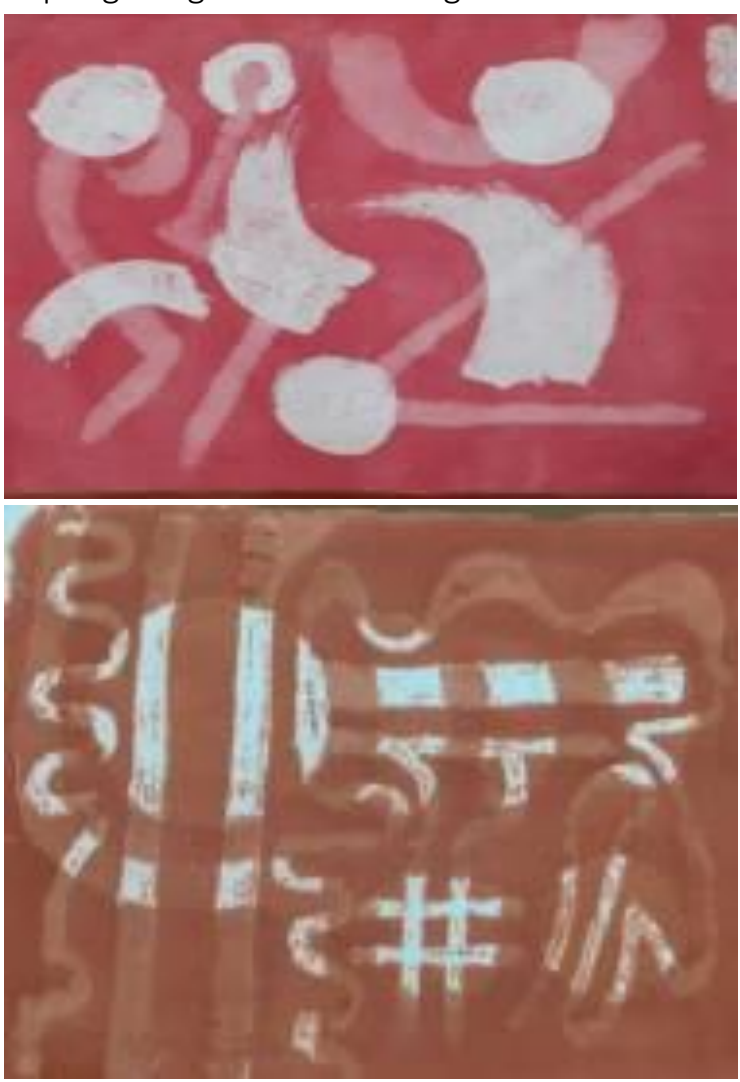

Tepung Terigu Masak Basah
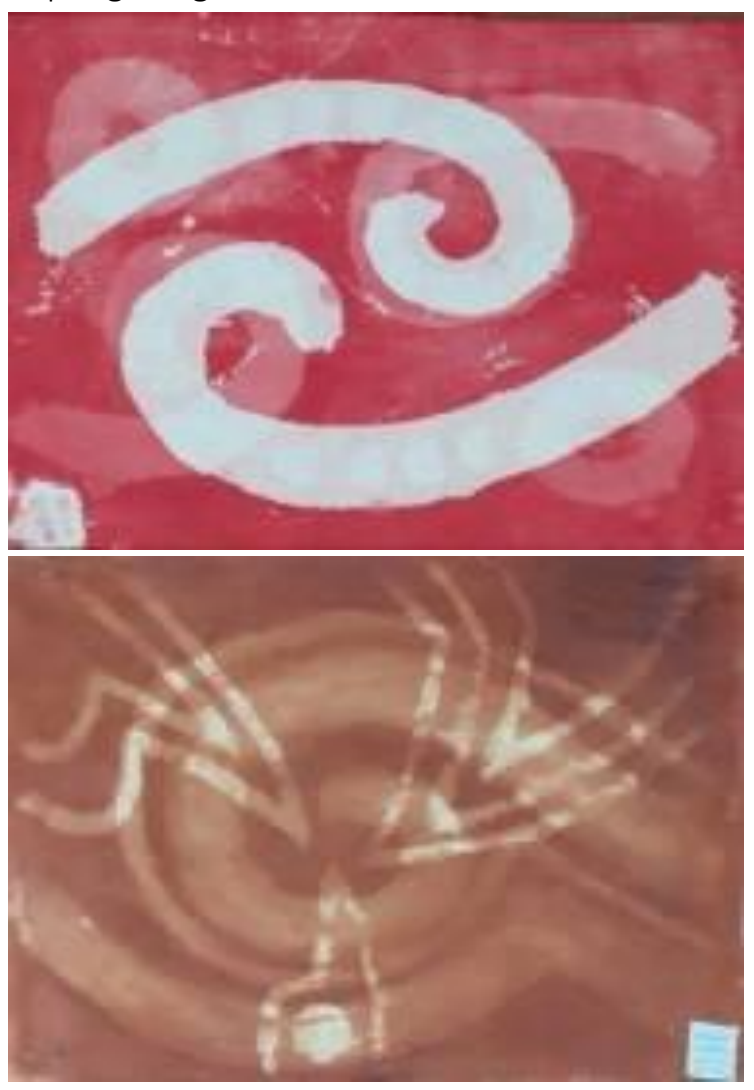

Tepung Terigu Masak Kering
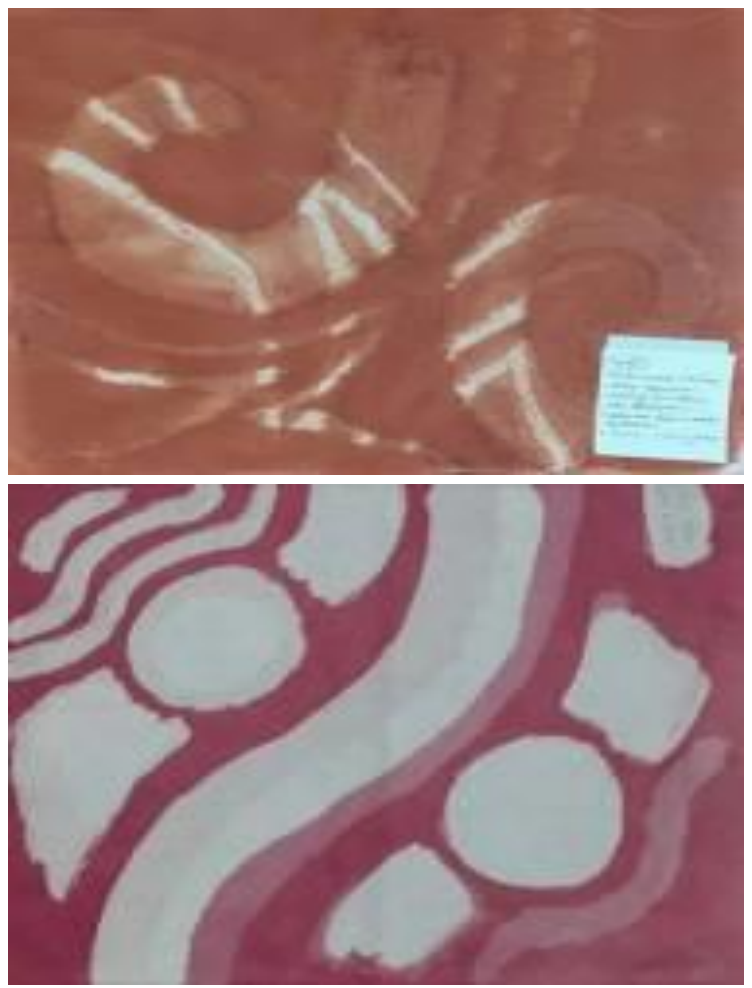


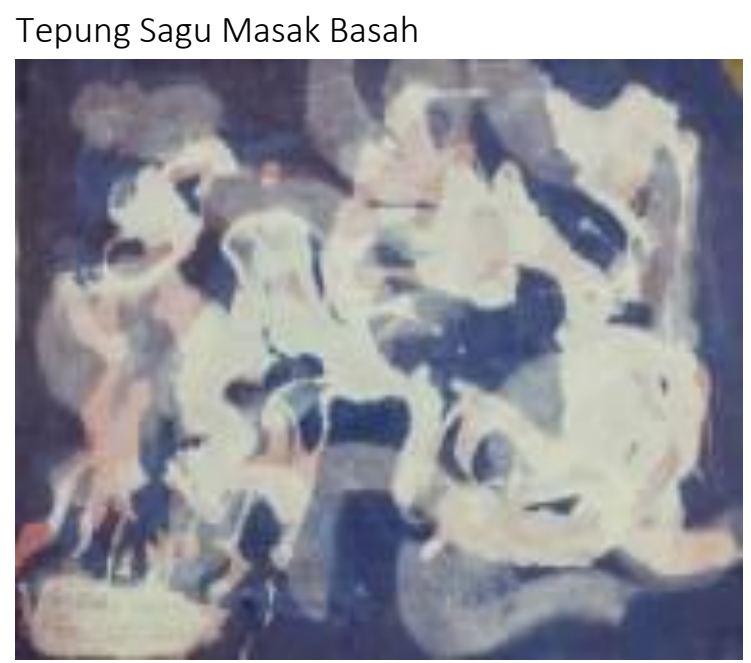

\section{Tepung Sagu Masak Kering}

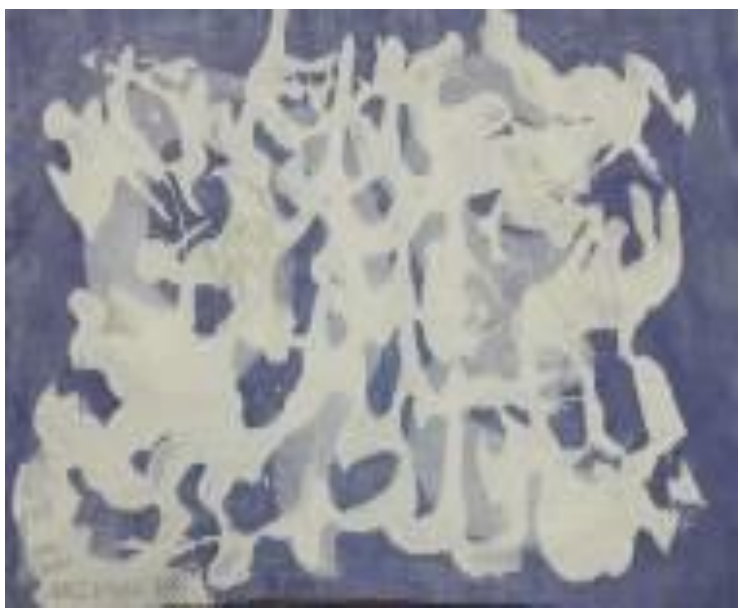

Tepung Maizena Mentah Basah

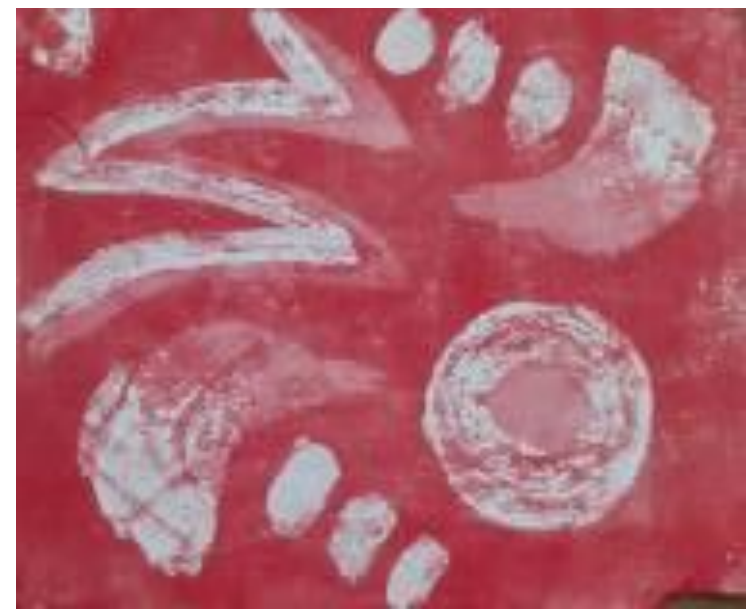

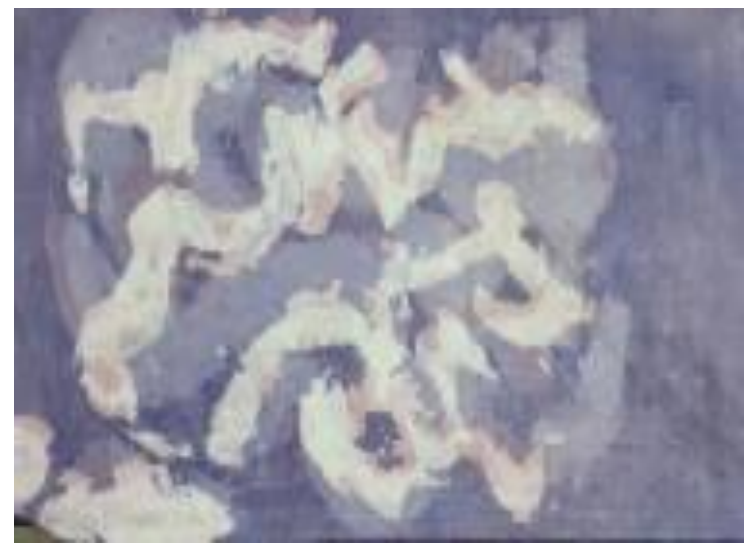

Tepung Maizena Masak Kering

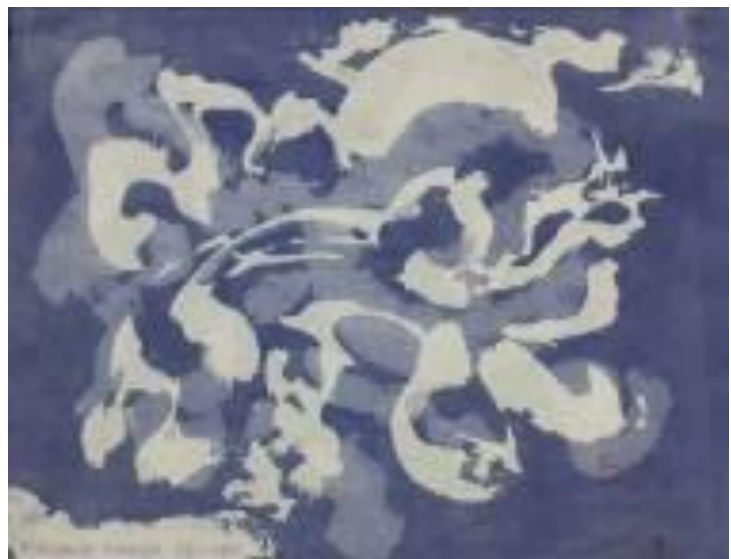

Tepung Terigu Mentah Masak Kering Malam

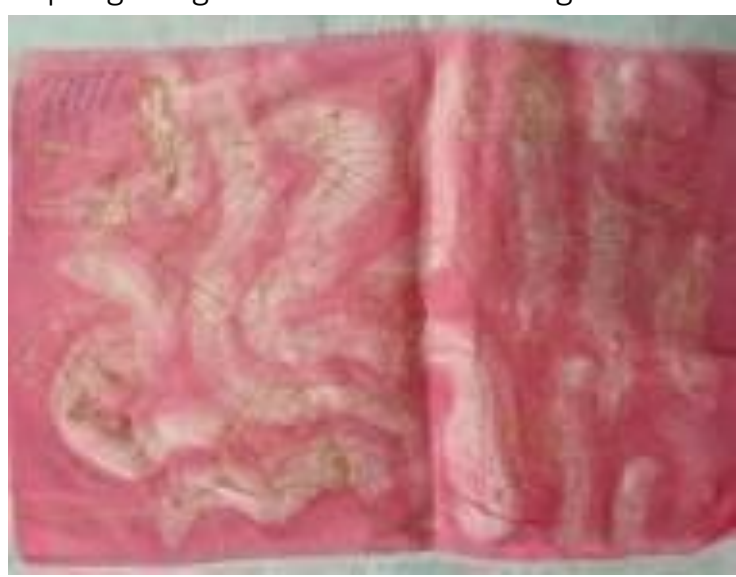

PEMBAHASAN

Pengaplikasian tepung makanan sebagai perintang warna pada kain merupakan deversifikasi bahan yang sebelumnya merupakan bahan makanan kemudian dapat 
juga dipakai sebagai alternatif perintang warna pada kain. Pada penelitian terapan ini digunakan kain sutra dan katun,hal ini untuk mengetahui hasilnya pada bahan yang berbeda Eksperimen ini dilakukan melalui beberapa tahap sesuai dengan jenis tepung yang dipakai.

Pada pengolahan tepung dilakukan dengan dua cara yaitu membuat adonan mentah dan membuat bubur dengan cara dimasak. Untuk bubur, ukuran yang dipakai adalah 30gr tepung dicampur dengan air 300cc kemudian dimasak hingga mengental. Bila menginginkan bubur lebih encer karena akan digunakan membuat goresan yang lebih cepat dan ekspresif maka ukurannya adalah 30gr tepung dicampur dengan air 400cc. Untuk adonan mentah hanya tepung terigu yang dapat dipakai karena ketika dibuat adonan terigu bisa mengental dan agak liat, sedang tepung yang lain tidak bisa mengental. Untuk adonan terigu mentah, ukurannya $35 \mathrm{gr}$ dengan air 100cc. Pengaplikasian adonan mentah dan bubur pada kain ada dua cara.

Cara pertama adalah dengan mengaplikasikan adonan mentah dan bubur di kain dalam keadaan basah, kemudian diwarna.

Cara yang kedua adalah dengan mengaplikasikan adonan mentah dan bubur dalam keadaaan basah lalu dikeringkan dan selanjutnya diwarna. Bubur masak lebih mudah dilekatkan ke kain dari pada adonan mentah karena bubur masak lebih licin.

Pewarnaan dilakukan dengan cara cepat mengingat adonan mentah maupun bubur dalam keadaan kering atau basah tidak bisa melekat kuat dan tidak stabil di kain sutra maupun katun sebagaimana perintang malam, maka zat warna yang bereaksi memunculkan warna dengan cepat menjadi pilihan yang tepat, yaitu pewarna kimia naphtol dan indigo sol.
Pengaplikasian adonan maupun bubur ini dapat dilakukan secara bolak balik pada kain dengan motif yang berbeda, sehingga ketika dilakukan pewarnaan, hasil pada kedua permukaan kain akan berbeda pula, sesuai dengan motif yang di torehkan pada masing masing sisinya. Terdapat tapak warna putih bersih pada permukaan bagian yang terkena adonan maupun bubur dan tapak warna muda atau lebih terang dari warna yang digunakan pada bagian permukaan sebaliknya yang tidak terkena adonan maupun bubur.

Penorehan adonan maupun bubur juga dapat dilakukan secara bolak-balik dalam posisi berhadapan, maka tapak warna pada kedua sisi permukaan kain akan berwarna putih bersih sedang yang tidak berhadapan akan berwarna putih bersih di satu sisi dan warna muda di sisi sebaliknya. Teknik ini juga dapat diterapkan untuk mempercepat proses pelorodan yakni tidak perlu dengan cara perebusan cukup dicuci bersih.

Dari eksperimen yang telah dilakukan, ditemukan bahwa semua tepung dapat digunakan sebagai perintang dengan hasil yang baik apabila tepung yang digunakan dimasak dahulu menjadi bubur. Untuk pengolesan perintang masak secara pelan maka maka ukuran bahan yang dipakai adalah 30gr tepung dengan air $300 \mathrm{cc}$, bila pengolesan secara ekspresif cepat maka dibutuhkan adonan yang lebih encer sehingga air ditambah menjadi 400 cc. Khusus untuk tepung terigu adonan mentah maka ukuran yang digunakan adalah 35gr terigu dengan 100cc air. 


\section{PROSES PEMBUATAN KARYA}

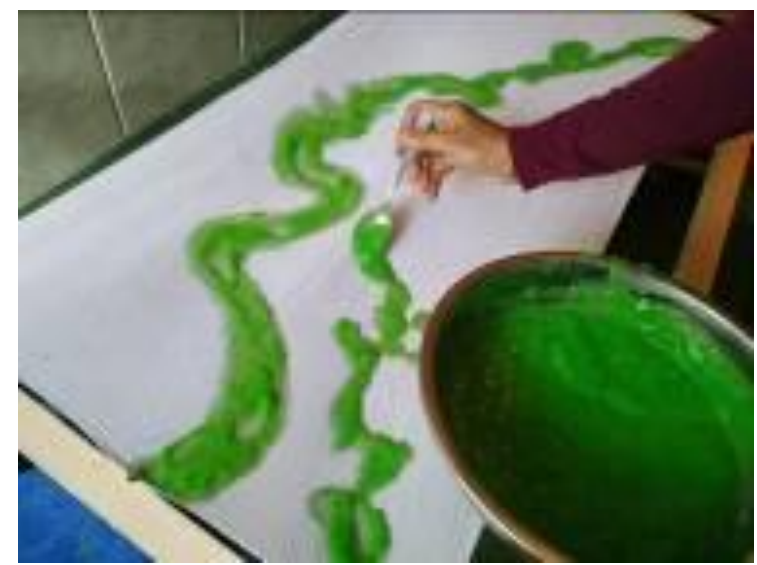

Perintangan dengan Bubur Terigu 1

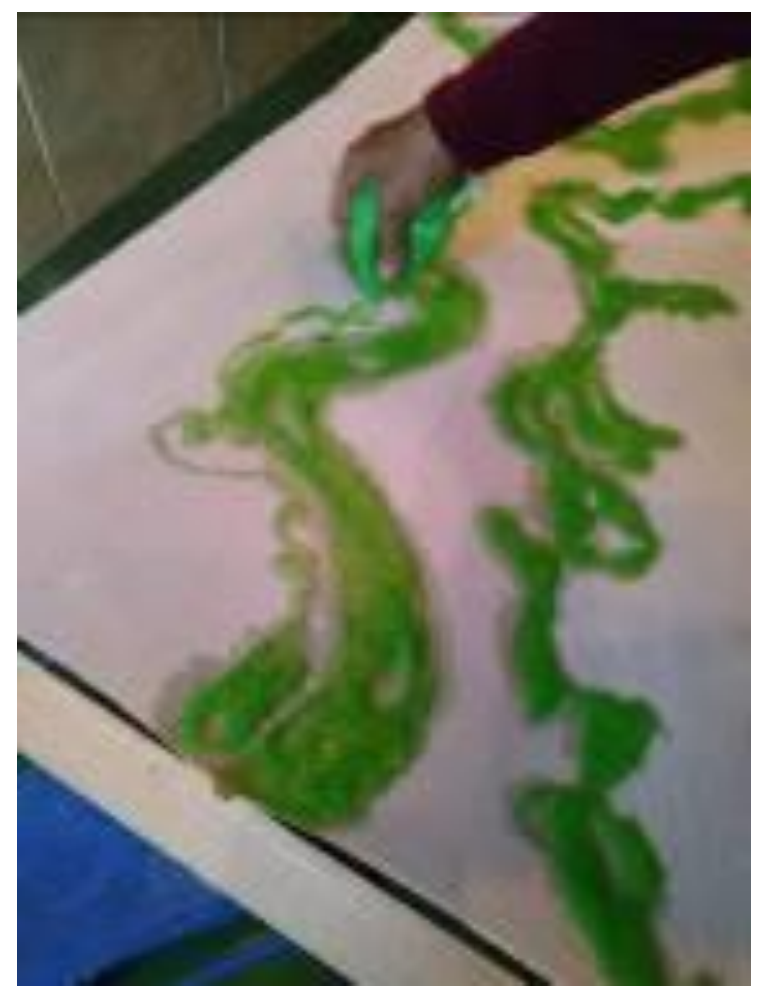

Perintangan dengan Bubur Terigu 2

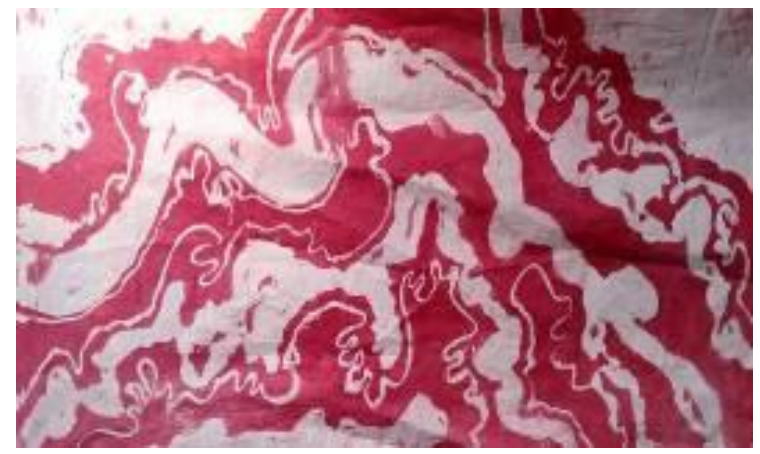

Pewarnaan Pertama

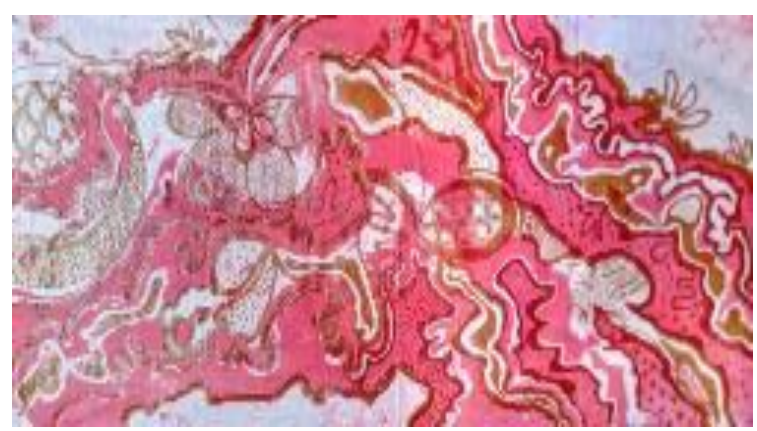

Pembatikan

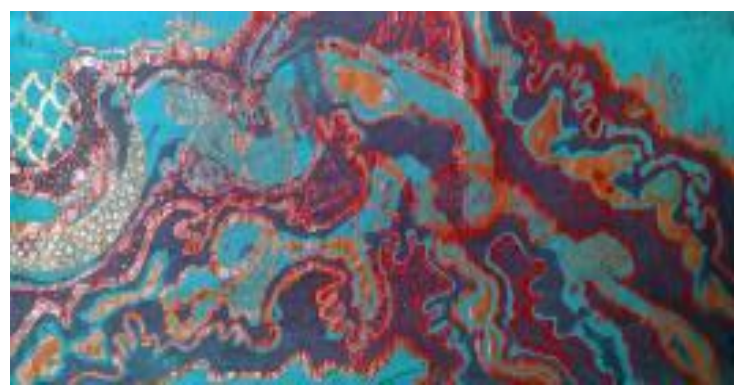

Pewarnaan Kedua

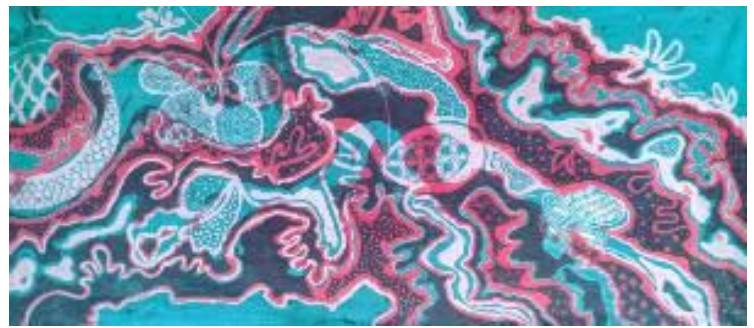

Hasil Karya Bolak Balik 


\section{HASIL KARYA}

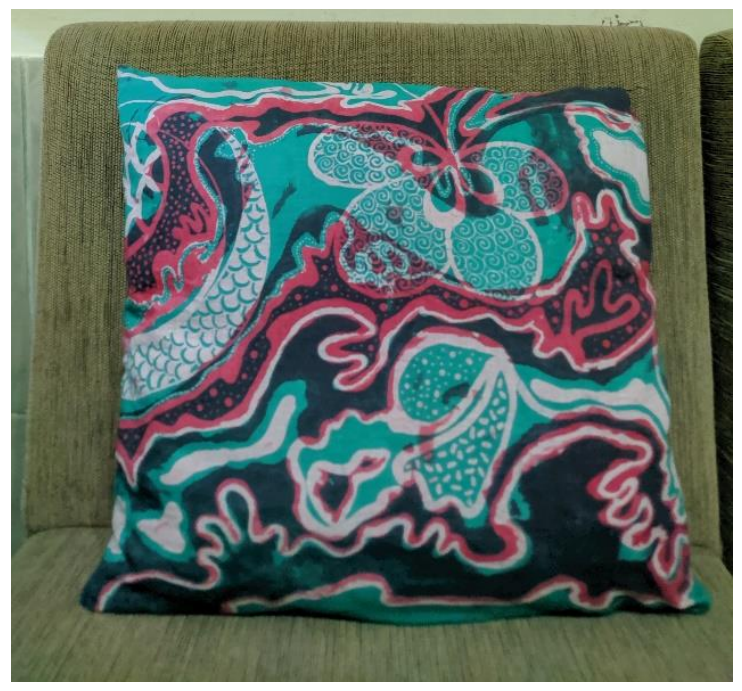

Karya Sarung bantal kursi, bahan katun,

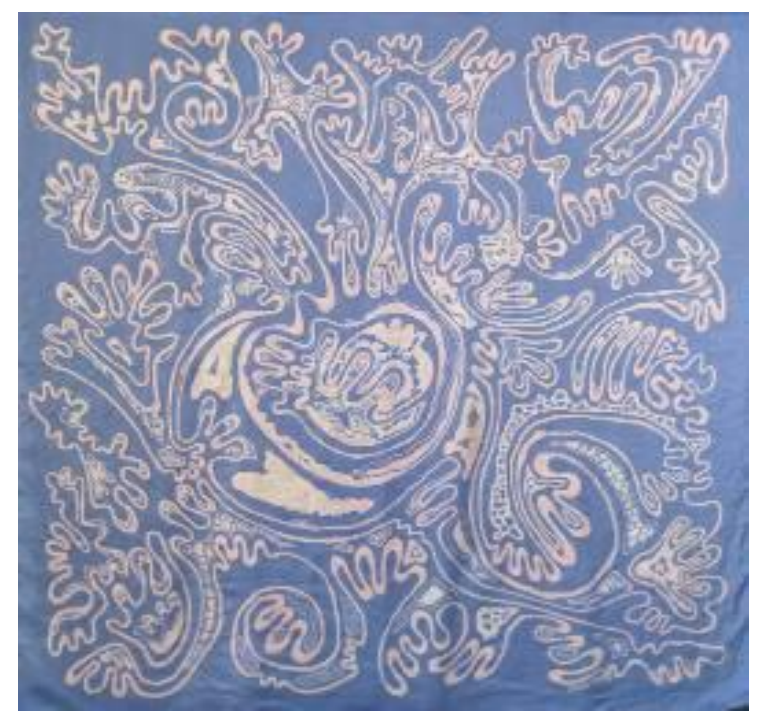

Karya Scarf, Bahan Sutra, Perintang Sagu

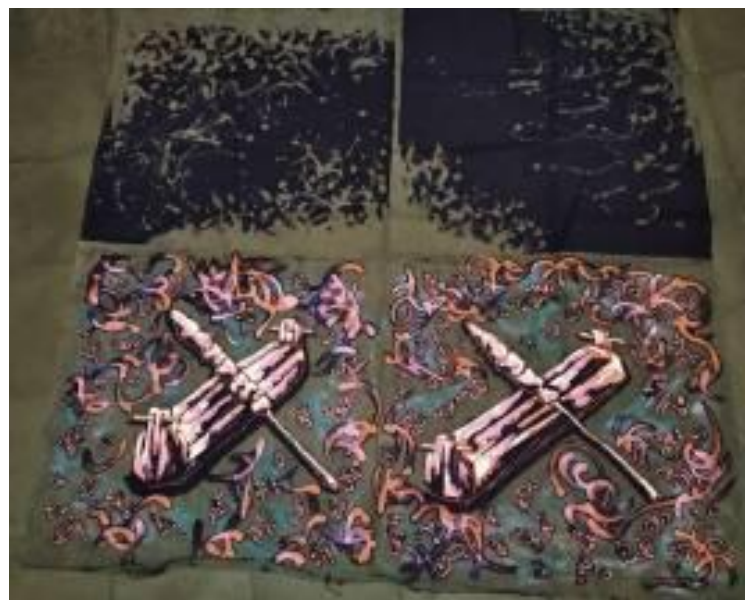

Karya Sarung Bantal Kursi, Perintang Terigu, Bahan Katun

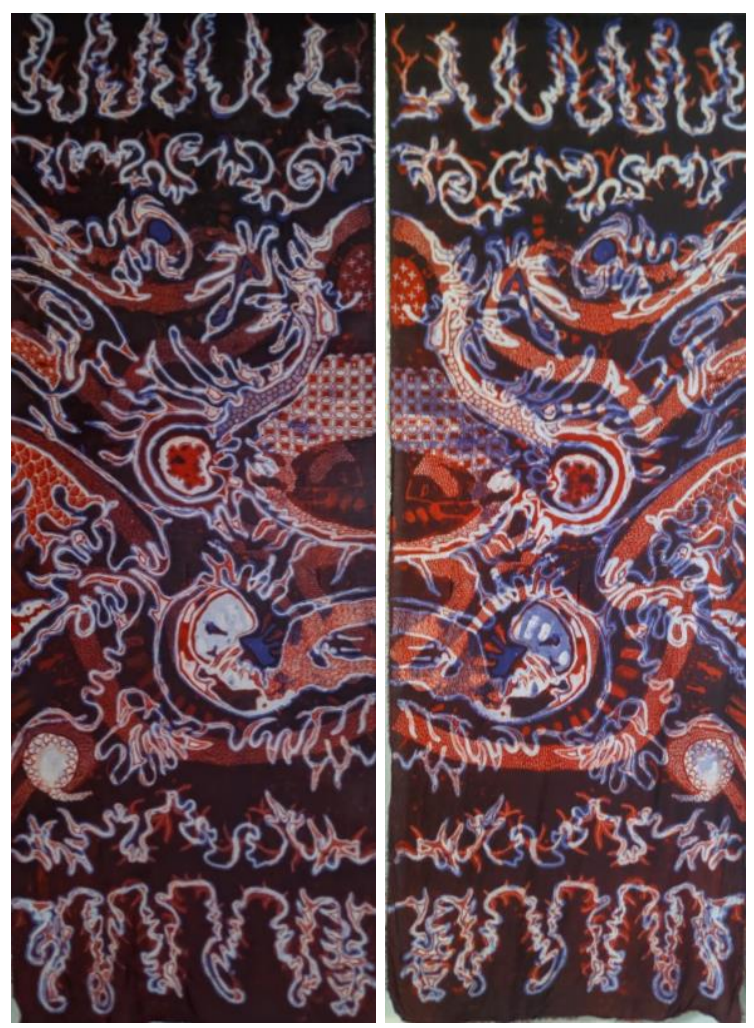

Karya Selendang 1 Tampak Depan dan Tampak Belakang 


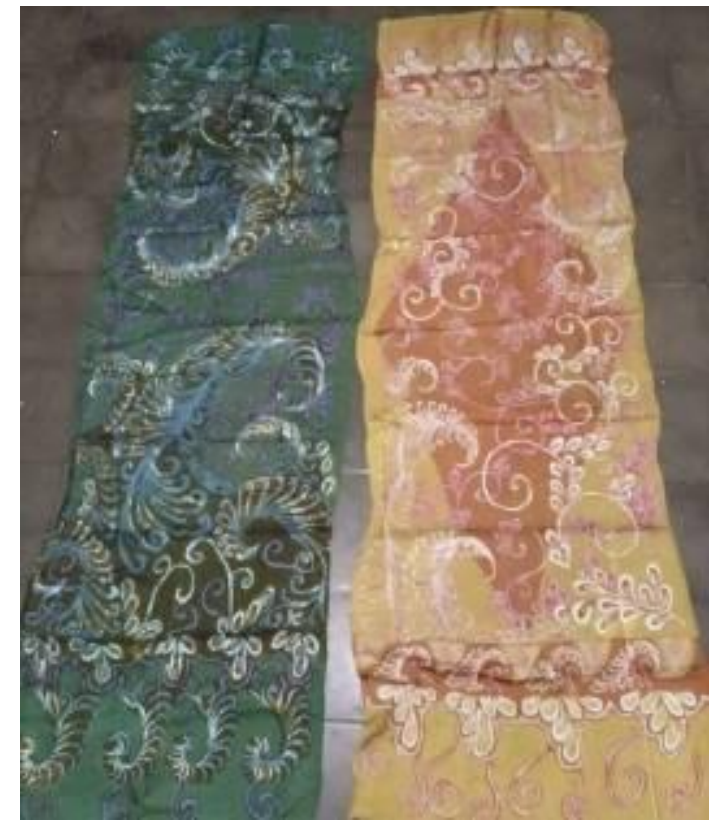

Karya Selendang, Perintang Sagu, Bahan Sutra

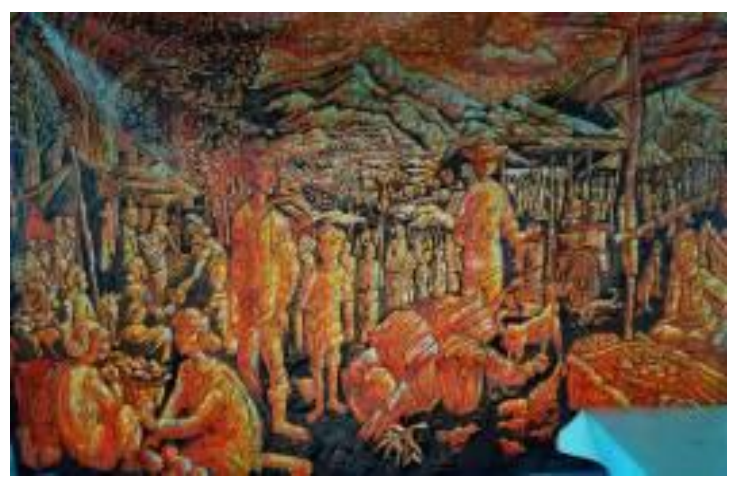

Karya Ekspresi

\section{PENUTUP}

Tepung terigu, tepung maizena, dan tepung sagu merupakan bahan makanan yang dapat dijadikan sebagai bahan perintang masuknya warna pada kain sutra maupun katun, sehingga bahan makanan tersebut dapat menjadi alternatif material non malam . Pada kain sutra dan katun, perintang dapat dilekatkan dalam kondisi adonan mentah maupun bubur masak, walaupun demikian bubur masak lebih mudah dilekatkan ke kain dari pada adonan mentah karena licin. Meski dalam keadaan basah, perintang tidak bisa tembus kain sehingga pelekatannya bisa dilakukan pada satu sisi atau kedua sisi kain. Melihat kondisi perintang tidak kuat dan tidak stabil melekatnya pada kain, maka pewarnaan dilakukan secara cepat menggunakan warna kimia dengan cara disemprot dan atau dicelup cepat, tidak bisa dilakukan dengan cara perendaman.

Pelekatan pada satu sisi permukaan kain meninggalkan tapak putih bersih dan pada sisi sebaliknya berwarna lebih terang dari warna yang digunakan, sedangkan pelekatan pada dua sisi pada area berhadapan menghasilkan tapak putih bersih di kedua sisi area tersebut. Ada 5 jenis karya seni tekstil yang dibuat dengan teknik rintang non malam yaitu kain panjang, selendang, sarung bantal kursi, dan scraf sebagai karya fungsional serta wall hanging atau hiasan dinding sebagai karya seni ekspresi. Teknik ini juga dapat diterapkan untuk mempercepat proses pelorodan yakni tidak perlu dengan cara perebusan cukup dicuci bersih.

\section{DAFTAR PUSTAKA}

Anas, Biranul, "Batik dalam Dinamika Budaya", Procceding Seminar Nasional Batik, Prodi. Seni Kerajinan FBS UNY, 2011

Dharsono, S. Kartika, Seni Rupa Modern, Rekayasa Sains, Bandung, 2004

Djumena, Nian S, Batik dan Mitra, Jambatan, Jakarta,1990

Gustami Sp., Butir-Butir Mutiara Estetika Timur: Ide Dasar Penciptaan Seni 
Kriya Indonesia, Prasista, Yogyakarta, 2007

Fitriani, Hanifah., "Pengolahan Kulit Umbi Singkong (Manihot Utilissima) di Kawasan Kampung Adat Cireundeu Sebagai Bahan Baku Alternatif Perintang Warna Pada Kain", eProceeding of Art \& Design: Vol 4, no. 3 Desember 2017

Hendriyana, Husen, Metodologi Penelitian Penciptaan Karya, Sunan Ambu Press, Bandung, 2018

Sachari, Agus, Pengantar Metodologi Penelitian Budaya Rupa, Jakarta, Erlangga, 2005 Desain-Desain Gaya dan Realitas, Indonesia:Studi Desain ITB,1987.

Sp., Soedarso, Tinjauan Seni Sebuah Pengantar untuk Apresiasi Seni, Saku Dayar Sana, Yogyakarta, 1990.

Trilogi Seni : Penciptaan Eksistensi dan Kegunaan Seni, Badan Penerbit ISI Yogyakarta, 2006.

Sariyati, Inva dan Utami, Prastiyo.," Pemanfaatan Pati Ganyong (Canna Edulis) Sebagai Bahan Baku Perintang Warna Pada Kain", Majalah Dinamika Kerajinan Dan Batik, Vol 35, no. 2, Desember 2018

Sedjati, Djandjang Purwo dan Sari, Vincentia Tunjung,"Mix Teknik Ecoprint dan Teknik Batik Berbahan Warna Tumbuhan dalam Penciptaan Karya
Seni Tekstil“, Corak: Jurnal Seni Kriya, Vol. 8, No. 1, Mei 2019

Sedjati, Djandjang Purwo., "Keben (Barringtonia Asiarica), Motif dan Pewarnaan Batik", Corak: Jurnal Seni Kriya, Vol. 8, No. 2, November 2019

Sumino, Perancangan Kain Simbut untuk Kriya Tekstil, Penelitian DIPA Tahun 2007, Lembaga Penelitian ISI Yogyakarta, September 2007

Suratmi.," Batik Sebagai Media Ekspresi", Tugas Akhir Prodi Kriya Seni, Jurusan Kriya, FSR, ISI Yogyakarta, 2000 


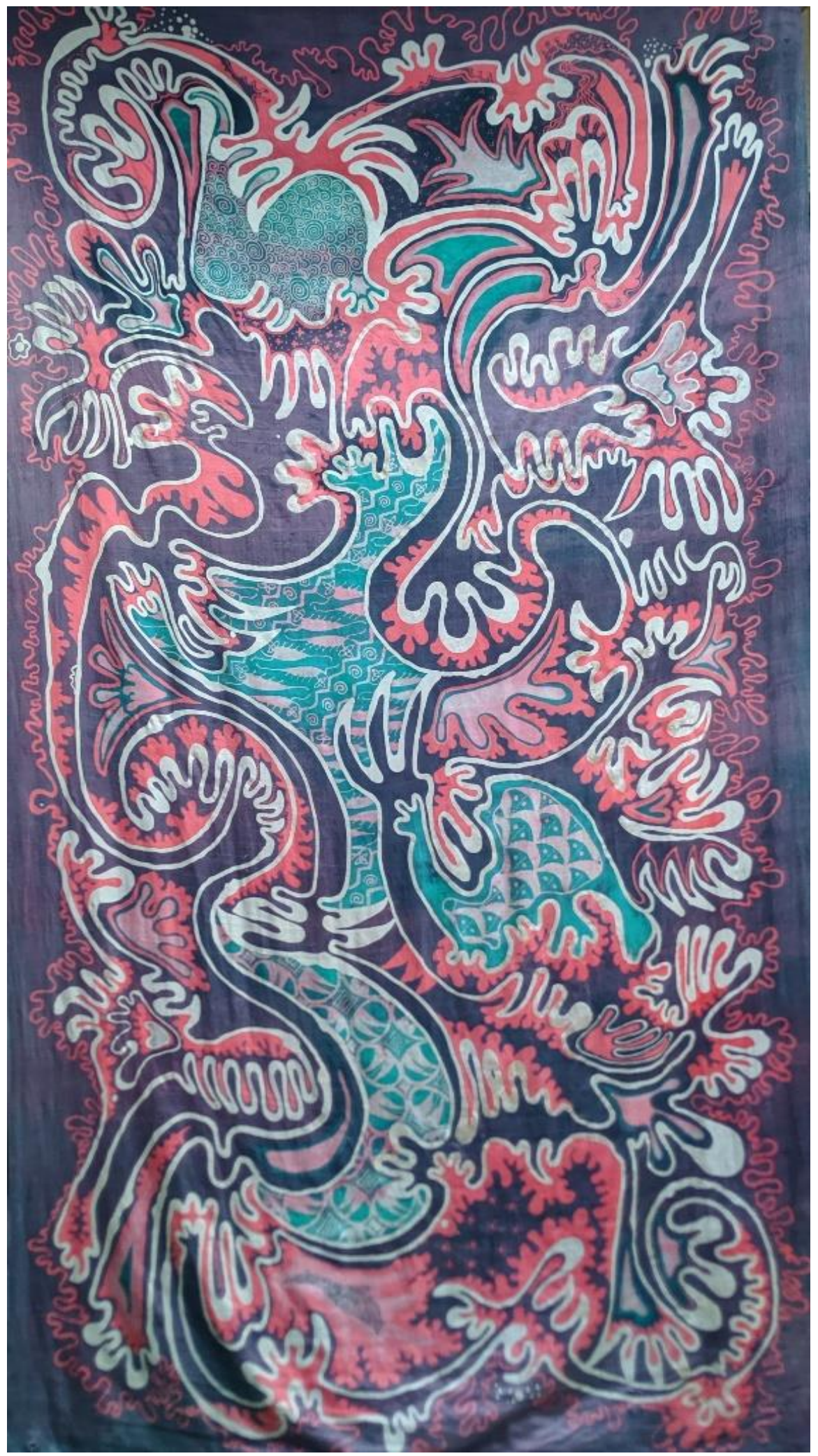

Karya Selendang 